\title{
Bud-, flower- and fruit-density in stone fruits
}

\author{
Szabó, Z. and Nyéki, J. \\ Debrecen University, Centre of Agricultural Science \\ H-4032 Debrecen, Böszörményi út 138.
}

\begin{abstract}
Summary: In 164 varieties of five stone fruit species, counts of flower buds, flowers and fruits set have been performed, regularly, between 1982 and 2002. The critical number and sample size has been determined for the purpose to estimate the yielding potential of peach plantations. For a rapid test, 10 shoots per variety are recommended. In sour cherry and peach varieties, the number and ratio of leaf and flower buds has been assessed on bearing shoots of different length.

The typical flower bud density of 129 peach varieties varies, as a rule, between 0.13 and $1.10 \mathrm{bud} / \mathrm{cm}$. Three groups of flower-bud-densities could be distinguished: low $(0-0.40 \mathrm{bud} / \mathrm{cm})$, intermediate $(0.41-0.60 \mathrm{bud} / \mathrm{cm})$, high (more than $0.60 \mathrm{bud} / \mathrm{cm})$. About $62 \%$ of varieties belong to the intermediate group. Negative correlation has been found between flower density and relative fruit set, whereas positive correlation between flower density and fruit yield.

The results are utilised in the description and choice of varieties, moreover, in choosing of optimal pruning policies. Varieties of high flower bud densities are recommended to be preferred for growing sites with frequent late frosts. Abundantly yielding varieties of low vegetative vigour are to be pruned more severely than those characterised by low yields, vigorous growth and low flower density. Sour cherry varieties, which are inclined to grow "whips" ought to be stimulated to grow longer shoots (40-50 cm per year), than varieties woid of that tendency $(30-40 \mathrm{~cm})$.
\end{abstract}

Key words: sweet cherry, sour cherry Japanese plum, European plum, apricot, peach, nectarine, flower bud density, flower density, fruit density

\section{Introduction}

The quantity of fruit grown world wide increases continuously. In regions of highly developed fruit production, the planting density as well as the mean yields are rising. In Hungary, however, fruit yields and the level of fruit production technologies declined, substancially, during the last 15 years. In the European Union, the criteria of economical farming are depending on regular as well as high quality yields. The amount and security of yields in stone fruits could be enhanced purposefully on the basis of an intrinsic knowledge related to the components of yield and their interaction.

We aimed the assessment of flower bud density, as an important character of varieties and groups of varieties as well as of stone fruit species, being tighly related to fruit density.

Fruit bud densities of stone fruit species was the subject of several studies, which dealt with a high number of varieties in sweet cherries - Druart (1996), peaches - Brózik (1962); Bellini \& Scaramuzzi (1976); Werner et al., 1988), PérezGonzalez (1993). Data of flower bud density are highly dependent on the method used, but a standardisation of the methods may reveale the real differences between varieties.

According to practical experiences we know that growth, at least a little, has to be maintained in order to achieve reglarular yields by keeping the continuous formation of flower buds as well as an optimal ratio of leaf and flower buds. Most of the sweet and sour cherry, plum and apricot varieties produce the majority of their fruits on short yielding structures. The best quality of peach fruits are grown on 40-80 cm-long shoots. Some varieties (e.g. Bigtop), however, have to be kept yielding due to higher flower densities with shorter shoots.

Cherry, plum and apricot growers, in Hungary as a rule, used to practice weak pruning (eliminating 10-20\% of yielding structures) and did not prune every year. Those were the conditions of the highest yields. However, for the sake of good quality, regular pruning would be necessary. That is a condition of growing every year long shoots (40-60 $\mathrm{cm})$, which are able to produce yielding spurs next year (Szabó et al. 1997). That pruning being relatively more severe (in cherry, plum and apricot) proved to be efficacious also in countries with highly developed fruit production (e.g. Italy and France). That is the reason why yields are maintained to be produced mainly on longer shoots.

\section{Material and method}

Between 1982 and 2002, the density of flower buds, flowers and fruits of sour cherry, European plum, Japanese plum, apricot and peach varieties have been counted regularly in four variety assortments, in Hungary, according to the following systems: 


\begin{tabular}{l|l|l|c|}
\multicolumn{1}{c|}{ Species } & \multicolumn{1}{c|}{ Growing site } & \multicolumn{1}{c|}{$\begin{array}{c}\text { Years of } \\
\text { observation }\end{array}$} & $\begin{array}{c}\text { Number of } \\
\text { varieties }\end{array}$ \\
\hline Sour cherry & Csány & 1988 & 6 \\
\hline Európean plum & Siófok & $1982-1985$ & 22 \\
\hline Japanese plum & Siófok & $1982-1985$ & 6 \\
\hline Apricot & Siófok & 2002 & 1 \\
\hline Peach & $\begin{array}{l}\text { Siófok, Szatymaz, } \\
\text { Szigetcsép }\end{array}$ & $\begin{array}{l}1986,1993,1994 \\
1997\end{array}$ & 129 \\
\hline
\end{tabular}

The plantations are made with virus-free grafts. Sour cherry, plum and apricot trees were spaced $7 \times 4 \mathrm{~m}$, peaches at $6 \times 4 \mathrm{~m}$. The understocks of the trees were Prunus mahaleb for sour cherry Prunus cerasifera v. myrobalana for plum and apricot and wild peaches, GF 655/2 and $G F$ 677, for peach. In sour cherry, the trees were trained with central leader system, the rest with open crowns. The cultivation matched the usually accepted level. The soil surface was kept clean with herbicides, watering has not been practiced.

Shoots of stone fruit species develop, separately, leaf and flower buds. The buds either burst in the spring or die, i.e. shoots and flowers are always produced on the growth of the last year.

The position of the buds is determined by the respective variety. At the distal end of a bearing shoot is always a leaf buds. In sweet and sour cherries, leaf and flower buds are singly distributed along the shoot. In plums, apricot and peach, the positions of buds is more variable. Not only single buds but also two buds may occur on the same bud base, one of them being a leaf bud, the other a flower bud, or between two flower bud one leaf bud (a mixed group of three buds), or more (3-4) flower buds around one leaf bud.

Within one flower bud there developed a single flower in apricot and peach, one or two flowers in European plum, 2 or 3 in Japanese plum, 2 to 5 flowers in sweet and sour cherries.

The base of the yield is the quantity of flower buds. In sour cherry, plum and peach the number of flower buds has been related to the length of the bearing shoots, i.e. the density flower buds per a unit $(\mathrm{cm})$ of the bearing shoots. According to this value, species and varieties are comparable.

In the literature, no indications have been found, which were the criteria of statistically required samples for the above purpose. Most frequently, the density of flower buds were determined in peaches, therefore, our calculations have been concentrated to that species. The number of data required has been determined by choosing in each group of varieties a low density ( $0.40 \mathrm{bud} / \mathrm{cm}$ or less), an intermediate $(0.41-0.60 \mathrm{bud} / \mathrm{cm})$ and a high density $(0.60 \mathrm{bud} / \mathrm{cm}$ or more) variety. The critical error of a sample of 10 data has been calculated according to the formula of Sváb (1981) at a level of probability: $\mathrm{P}=5 \%$. This way, the number of shoots to be sampled has been fixed. The varietal means could be assessed at an accuracy of \pm 0.05 bud/shoot $\mathrm{cm}$ by counting a sample of 9 to 83 shoots, 38 as a mean (Table I). If an accuracy of \pm 0.1 bud/shoot $\mathrm{cm}$ were sufficient, then 2-15 shoots, 9 as a mean are required. For the pracice, a rapid orientation may be based on the counts performed on 10
Table $I$ The number of shoots necessary to estimate flower bud density of peach varieties (Szigetcsép, 1993)

\begin{tabular}{|c|c|c|c|c|}
\hline \multirow{3}{*}{$\begin{array}{l}\text { Type and } \\
\text { variety }\end{array}$} & \multirow{2}{*}{\multicolumn{2}{|c|}{$\begin{array}{l}\text { Flower bud density } \\
\text { (bud/cm) }\end{array}$}} & \multicolumn{2}{|c|}{ Number of shoots examined } \\
\hline & & & 0.05 (bud $/ \mathrm{cm})$ & 0.1 (bud $/ \mathrm{cm})$ \\
\hline & mean & error & \multicolumn{2}{|c|}{ at an error admitted } \\
\hline \multicolumn{5}{|c|}{ Fresh consumption, yellow flesh varieties } \\
\hline Lisbeth & 0.39 & 0.141 & 40.6 & 10.2 \\
\hline Collins & 0.51 & 0.202 & 83.4 & 20.9 \\
\hline \multicolumn{5}{|c|}{ Fresh consumption, white flesh varieties } \\
\hline Michelini & 0.39 & 0.065 & 8.6 & 2.2 \\
\hline Raritan Rose & 0.62 & 0.171 & 59.7 & 14.9 \\
\hline \multicolumn{5}{|c|}{ Processing type varieties } \\
\hline Babygold 6 & 0.31 & 0.134 & 36.7 & 9.2 \\
\hline Frederica & 0.60 & 0.109 & 24.3 & 6.1 \\
\hline \multicolumn{5}{|l|}{ Nectarines } \\
\hline Maria Laura & 0.36 & 0.103 & 21.7 & 5.4 \\
\hline Nectagrand 1 & 0.83 & 0.114 & 26.6 & 6.7 \\
\hline Mean & 0.50 & & 37.7 & 9.4 \\
\hline
\end{tabular}

(Source: Szabó, Z. non published)

shoots as a sample. Higher accuracy might be achieved if we caculate the critical sample size according to the formula mentioned (Sváb, 1981) for each particular variety.

In sour cherry and peach, also the density of leaf buds has been studied. In sour cherry, shoots have been separated into 7 categories by $10 \mathrm{~cm}$ intervals according to their length. In peaches, three categories have been determined: long (above $60 \mathrm{~cm})$, intermediate $(40-60 \mathrm{~cm})$, short $(10-40$ $\mathrm{cm}$ ) as bearing shoots, and spurs (below $10 \mathrm{~cm}$ ). In order to characterise varieties or variety-types, we took samples of 5-10 bearing shoots during the rest period.

In peach, Mohácsy et al. (1959) recommended a pattern to distinguish the bud bases: (1) no bud, (2) 1 leaf bud, (3) 1 flower bud, (4) 1 leaf and 1 flower bud, (5) 1 leaf and 2 flower buds, (6) others (e.g. 2 flower buds).

Flower density has been observed in plums at blooming time and expressed in flower/shoot $\mathrm{cm}$ units.

In peaches, flower density has been observed at full bloom, fruit density at ripening. The $0-10$ scale of density has been applied, as 0 represented a barren tree, whereas, 10 meant the maximal load of flowers or fruits.

\section{Results and discussion}

Data related to the density of flower buds and of flowers in stone fruits as treated in the relevant literature were summarised and compared with our own data in Table 2. A comparison of the species is also possible. Between species and varieties within the species there are multiple differences in the number of flower buds related to the length of shoot. Outstanding data are found in Japanese plum and apricot. Intermediate data characterise the European plum, sour cherry and peach as for the flower bud density, and low in sweet cherry. The data refer to long bearing shoots (above 40 $\mathrm{cm}$ ). Shorter shoots (below $40 \mathrm{~cm}$ ) display higher flower bud 
Table 2 Comparison of the densities of flower buds and flowers in stone fruit species

\begin{tabular}{|c|c|c|c|c|c|c|c|c|c|c|c|c|c|c|}
\hline \multirow[t]{2}{*}{ Species } & \multirow[t]{2}{*}{$\begin{array}{l}\text { Number of } \\
\text { varieties }\end{array}$} & \multicolumn{3}{|c|}{$\begin{array}{l}\text { Flower bud density } \\
\text { (bud/cm) }\end{array}$} & \multicolumn{3}{|c|}{$\begin{array}{l}\text { Flower density } \\
\text { (bud/cm) }\end{array}$} & \multicolumn{3}{|c|}{$\begin{array}{c}\text { Number of flowers } \\
\text { (flower } / \mathrm{cm} \text { ) }\end{array}$} & \multicolumn{3}{|c|}{$\begin{array}{l}\text { Ratio of flower buds } \\
(\%)\end{array}$} & \multirow[t]{2}{*}{ Source } \\
\hline & & $\min$. & $\max$. & mean & $\min$. & $\max$ & mean & $\min$. & $\max$. & mean & $\min$. & $\max$. & mean & \\
\hline Sweet cherry & $\begin{array}{c}12 \\
9 \\
\end{array}$ & 0.10 & 0.33 & 0.18 & & & & 2.39 & 3.30 & 2.84 & & & & $\begin{array}{l}\text { Salgim (1990) } \\
\text { Druart (1996) }\end{array}$ \\
\hline Sour cherry & $\begin{array}{c}22 \\
1 \\
6 \\
10\end{array}$ & 0.39 & 0.64 & 0.49 & 1.23 & 2.55 & 1.78 & 2.22 & 3.91 & 3.18 & 46 & 66 & $\begin{array}{c}48.3 \\
58\end{array}$ & $\begin{array}{l}\text { Pozvai et al. (1982) } \\
\text { Rasmussen et al. (1983) } \\
\text { Kovács, S.- Katona, É.- } \\
\text { Szabó, Z. non published } \\
\text { Salgim (1990) }\end{array}$ \\
\hline European plun & $\begin{array}{c}1 \\
22 \\
\end{array}$ & 0.38 & 1.37 & $\begin{array}{l}0.48 \\
0.73 \\
\end{array}$ & 0.45 & 2.12 & 1.14 & 1.2 & 2.2 & 1.59 & & & 54.5 & $\begin{array}{l}\text { Hassib (1966) } \\
\text { Szabó, Z. (1989) }\end{array}$ \\
\hline Japanese plum & 6 & 1.03 & 2.69 & 1.66 & 1.73 & 3.59 & 2.45 & 1.3 & 1.7 & 1.52 & & & & Szabó, Z. (1989) \\
\hline Apricot & $\begin{array}{l}5 \\
1 \\
\end{array}$ & & & 1.65 & & & & & & 1 & & & & $\begin{array}{l}\text { Brózik, S. (1960) } \\
\text { Szabó, Z. non published }\end{array}$ \\
\hline Peach & $\begin{array}{c}20 \\
89 \\
50 \\
129\end{array}$ & $\begin{array}{l}0.16 \\
0.24 \\
0.08 \\
0.13\end{array}$ & $\begin{array}{l}0.81 \\
0.94 \\
1.35 \\
1.10\end{array}$ & $\begin{array}{l}0.48 \\
0.51 \\
0.48 \\
0.49\end{array}$ & & & & & & $1-2$ & 7.1 & 80.0 & 56.8 & $\begin{array}{l}\text { Brózik, S (1962) } \\
\text { Kovács, S. non published } \\
\text { Pérez \& Gonzalez (1993) } \\
\text { Szabó, Z. non published }\end{array}$ \\
\hline
\end{tabular}

densities. Flower density depends also on the number of flower primordia per flower bud. This value is 1 in apricot and peach, around 1.5 in European and Japanese plums. During the survey of frost damage, as many as $2-4$ flower primordia per flower have been found in Japanese plum. If the frost damage did not impair them during the winter, more than two flowers per bud may develop. In sweet and sour cherry buds three flowers may appear. Alltogether, higher flower densities are observed in Japanese plum. In peach and apricot flower buds is mainly one single flower also according to the relevant literature, that means flower bud density is taken identical with flower density, if no frost damage occurred. Among species, peaches represents the lowest flower densities. According to the literature, the ratio of flower buds may surpass $50 \%$ also on long (above $40 \mathrm{~cm}$ ) bearing shoots in sour cherry, European plum and peach. Related to the latter species, Japanese plum and apricot produces higher flower bud densities, thus the ratio of flower buds is higher than $50 \%$ in these two species too.

The short bearing shoots (below $40 \mathrm{~cm}$ ) bear more flower buds than the long ones (above $40 \mathrm{~cm}$ ) according to all literary data, in sour cherry (Rasmussen et al., 1983); European plum (Hassib, 1966, Wustenberghs et al., 1994); and peach (Brózik, 1960, Mohácsy et al., 1959).

\section{Evaluation of the species}

\section{Sour cherry}

Single buds are grown in sour cherry, leaf and flower buds along the length of the shoots. The internodia of sour cherry shoots are longer at mid of the shoot, shorter at the base and the tip (Rasmussen et al., 1983). Flower buds are located on the lower and upper part, whereas on the central region leaf buds are placed. They observed that chances of fruit set are lower on shoots longer than $40 \mathrm{~cm}$. The reason of it is a reduced tendency of flower bud initiation on longer shoots, perhaps because of the slower differenciation.

During the winter of 1988 seven sour cherry varieties are studied as for the buds on bearing shoots of different length. Shoot length and the number of (all kind of) buds are positively correlated. The results are summarised in Table 3. Most the flower buds developed on $30-40 \mathrm{~cm}$ shoots of the variety Keceli $I$ and Újfehértói fürtös. The ratio of flower buds declined, however, with the increasing length of the shoot. The quantity of leaf buds was also positively correlated with the length of the shoot. In Körösi korai, the only leaf bud appeared on the tip of $10 \mathrm{~cm}$-long shoots, in other varieties, the same was true on the tip of up to $20 \mathrm{~cm}$ long shoots.

Highest flower bud density has been found on $20-40 \mathrm{~cm}$ long shoots. Relations of shoot length and bud density is expressed in Figure 1. On the longest (above $60 \mathrm{~cm}$ ) shoots may also appear flower buds at the base and near the tip regions at different ratios depending on the variety in question.

Correlation exists between the length of internodia and the appearance of different bud types (flower or laf buds) of the respective region. The short internodia of short shoots produce a high frequency of flower buds. Medium long bearing shoots differciate flower buds on the base and the tip region, where internodia are shorter. Near to the long 
Table 3 Quantities and rates of flower buds and leaf buds grown on shoots of different length in sour cherry varieties and clones (Csomád, 1988)

\begin{tabular}{|c|c|c|c|c|c|c|c|}
\hline Variety & 1 & 2 & 3 & 4 & 5 & 6 & 7 \\
\hline Pándy meggy & $\begin{array}{c}1 \\
2 \\
3 \\
4 \\
5 \\
6 \\
7 \\
\text { Mean } \\
\end{array}$ & $\begin{array}{l}2.04 \\
2.32 \\
2.94 \\
3.40 \\
3.70 \\
4.10 \\
4.64 \\
3.32 \\
\end{array}$ & $\begin{array}{l}8.60 \\
10.00 \\
13.00 \\
18.60 \\
19.60 \\
20.20 \\
23.40 \\
16.20 \\
\end{array}$ & $\begin{array}{c}7.20 \\
8.80 \\
11.20 \\
13.00 \\
8.80 \\
6.60 \\
6.40 \\
8.86 \\
\end{array}$ & $\begin{array}{c}1.40 \\
1.20 \\
2.20 \\
5.60 \\
10.80 \\
13.60 \\
17.00 \\
7.40 \\
\end{array}$ & $\begin{array}{l}0.84 \\
0.88 \\
0.86 \\
0.70 \\
0.46 \\
0.33 \\
0.27 \\
\mathbf{0 . 6 2} \\
\end{array}$ & $\begin{array}{l}1.02 \\
0.60 \\
0.48 \\
0.37 \\
0.19 \\
0.12 \\
0.10 \\
\mathbf{0 . 4 1} \\
\end{array}$ \\
\hline Kôrösi korai & $\begin{array}{c}1 \\
2 \\
3 \\
4 \\
5 \\
6 \\
7 \\
\text { Mean }\end{array}$ & $\begin{array}{l}2.20 \\
2.12 \\
2.66 \\
3.22 \\
3.80 \\
3.50 \\
4.60 \\
3.17 \\
\end{array}$ & $\begin{array}{c}9.00 \\
11.80 \\
18.60 \\
19.80 \\
25.40 \\
23.40 \\
34.20 \\
\mathbf{2 0 . 3 1} \\
\end{array}$ & $\begin{array}{l}7.80 \\
9.20 \\
9.80 \\
7.80 \\
7.40 \\
4.80 \\
5.80 \\
7.51\end{array}$ & $\begin{array}{c}1.20 \\
2.60 \\
8.80 \\
12.00 \\
18.00 \\
18.60 \\
28.40 \\
12.80 \\
\end{array}$ & $\begin{array}{l}0.86 \\
0.78 \\
0.53 \\
0.39 \\
0.29 \\
0.21 \\
0.17 \\
\mathbf{0 . 4 6}\end{array}$ & $\begin{array}{l}1.15 \\
0.62 \\
0.40 \\
0.23 \\
0.16 \\
0.09 \\
0.09 \\
\mathbf{0 . 3 9} \\
\end{array}$ \\
\hline Keceli 1 & $\begin{array}{c}1 \\
2 \\
3 \\
4 \\
5 \\
6 \\
7 \\
\text { Mean } \\
\end{array}$ & $\begin{array}{l}3.20 \\
2.98 \\
2.78 \\
3.50 \\
4.20 \\
4.58 \\
4.20 \\
3.76 \\
\end{array}$ & $\begin{array}{l}14.80 \\
11.20 \\
15.80 \\
21.00 \\
23.00 \\
26.00 \\
24.60 \\
19.49 \\
\end{array}$ & $\begin{array}{l}13.40 \\
10.20 \\
13.80 \\
17.40 \\
9.60 \\
8.60 \\
4.40 \\
11.06 \\
\end{array}$ & $\begin{array}{c}1.40 \\
1.00 \\
2.00 \\
3.60 \\
13.40 \\
17.40 \\
20.20 \\
8,04 \\
\end{array}$ & $\begin{array}{l}0.91 \\
0.91 \\
0.87 \\
0.83 \\
0.42 \\
0.33 \\
0.18 \\
\mathbf{0 . 6 4} \\
\end{array}$ & $\begin{array}{l}2.18 \\
0.81 \\
0.56 \\
0.51 \\
0.21 \\
0.16 \\
0.07 \\
\mathbf{0 . 6 4} \\
\end{array}$ \\
\hline Ujfehértói fürtös & $\begin{array}{c}1 \\
2 \\
3 \\
4 \\
5 \\
6 \\
7 \\
\text { Mean } \\
\end{array}$ & $\begin{array}{l}2.44 \\
2.08 \\
2.50 \\
3.04 \\
3.66 \\
4,60 \\
4.50 \\
3,26 \\
\end{array}$ & $\begin{array}{c}8.80 \\
12.40 \\
19.20 \\
20.00 \\
23.20 \\
26,00 \\
28,20 \\
19,00 \\
\end{array}$ & $\begin{array}{c}7.80 \\
11.40 \\
15.20 \\
16.60 \\
14.60 \\
7.60 \\
10,00 \\
\mathbf{1 1 , 8 9} \\
\end{array}$ & $\begin{array}{c}1.00 \\
1.00 \\
4.00 \\
3.40 \\
8.60 \\
19,20 \\
18,20 \\
7,91 \\
\end{array}$ & $\begin{array}{l}0.89 \\
0.92 \\
0.79 \\
0.83 \\
0,63 \\
0,29 \\
0,35 \\
\mathbf{0 , 6 7} \\
\end{array}$ & $\begin{array}{l}1.66 \\
0.81 \\
0.61 \\
0.47 \\
0,33 \\
0,14 \\
0,15 \\
\mathbf{0 , 6 0} \\
\end{array}$ \\
\hline Érdi bốtermố & $\begin{array}{c}1 \\
2 \\
3 \\
4 \\
5 \\
6 \\
7 \\
\text { Mean } \\
\end{array}$ & $\begin{array}{l}2,52 \\
2,38 \\
2,90 \\
3.44 \\
4,06 \\
4.44 \\
4.24 \\
3.43 \\
\end{array}$ & $\begin{array}{c}8,20 \\
11,00 \\
15,00 \\
16.60 \\
23.00 \\
23.80 \\
27.00 \\
17.80 \\
\end{array}$ & $\begin{array}{c}7,20 \\
10,00 \\
13.00 \\
11.00 \\
13.20 \\
3.20 \\
6.40 \\
9.14 \\
\end{array}$ & $\begin{array}{c}1,00 \\
1,00 \\
2,00 \\
5.60 \\
9.80 \\
20.60 \\
20.60 \\
8.66 \\
\end{array}$ & $\begin{array}{l}0,88 \\
0,91 \\
0,87 \\
0.66 \\
0.57 \\
0.13 \\
0.24 \\
\mathbf{0 . 6 1} \\
\end{array}$ & $\begin{array}{l}1,21 \\
0.64 \\
0.48 \\
0.32 \\
0.30 \\
0.06 \\
0.10 \\
\mathbf{0 . 4 4} \\
\end{array}$ \\
\hline Ërdi jubileum & $\begin{array}{c}1 \\
2 \\
3 \\
5 \\
6 \\
7 \\
\text { Mean } \\
\end{array}$ & $\begin{array}{l}2.14 \\
2.20 \\
2.60 \\
3.54 \\
4.32 \\
5.00 \\
\mathbf{3 . 2 0} \\
\end{array}$ & $\begin{array}{c}8.00 \\
13.60 \\
21.80 \\
23.80 \\
28.00 \\
30.60 \\
\mathbf{2 0 . 8 0} \\
\end{array}$ & $\begin{array}{c}6.80 \\
12.20 \\
14.00 \\
7.60 \\
10.20 \\
9.00 \\
\mathbf{1 0 . 3 7} \\
\end{array}$ & $\begin{array}{l}1.20 \\
1.40 \\
7.80 \\
16.20 \\
17.80 \\
21.60 \\
\mathbf{1 0 . 4 3} \\
\end{array}$ & $\begin{array}{l}0.85 \\
0.90 \\
0.64 \\
0.32 \\
0.36 \\
0.29 \\
\mathbf{0 . 5 7} \\
\end{array}$ & $\begin{array}{l}1.08 \\
0.84 \\
0.63 \\
0.16 \\
0.19 \\
0.14 \\
\mathbf{0 . 4 9} \\
\end{array}$ \\
\hline $\mathrm{SD}_{5 \%}$ & $\begin{array}{l}\text { A } \\
\text { B } \\
\text { C }\end{array}$ & $\begin{array}{l}0.47 \\
0.48 \\
0.21\end{array}$ & $\begin{array}{l}4.33 \\
4.27 \\
1.46\end{array}$ & $\begin{array}{l}4.54 \\
4.49 \\
1.58\end{array}$ & $\begin{array}{l}5.26 \\
5.16 \\
1.71\end{array}$ & $\begin{array}{l}0.18 \\
0.18 \\
0.08\end{array}$ & $\begin{array}{l}0.26 \\
0.26 \\
0.09\end{array}$ \\
\hline
\end{tabular}

(Source: Kovács, S.-Katona, É. -Szabó, Z. non published)

Explanation to Table 3:

$1=$ Length category

$2=$ Diameter $(\mathrm{mm})$

$3=$ Total number of buds

$4=$ Number of flower buds

$5=$ Number of leaf buds

$6=$ Flower buds $/$ Total of buds

$7=$ Flower buds $/$ shoot length (buds $/ \mathrm{cm}$ )
Length categories:

$1=10 \mathrm{~cm}$ and less

$2=10-20 \mathrm{~cm}$

$3=20-30 \mathrm{~cm}$

$4=30-40 \mathrm{~cm}$

$5=40-50 \mathrm{~cm}$

$6=50-60 \mathrm{~cm}$

$7=60-70 \mathrm{~cm}$.
$\mathrm{SD}_{5 \%}$

$\mathrm{A}=$ Between categories within the same variety

$B=$ Between any categories of any variety

$\mathrm{C}=$ Between varieties 
internodia of vigorous shoots, preferably, vegetative buds are differentiated.

Varieties inclined to develop "whips" (long, severalyear-old, unbranehed axes) are known to develop few leaf buds also on the long shoots, which has been experienced in Pándy meggy, Keceli 1 and Újfehértói fürtös, as on the $30-40 \mathrm{~cm}$-long shoots they show a low density of leaf buds (3.6-5.6 buds/shoot). Varieties characterised as developing "whips" (Kốrösi korai, Érdi jubileum) display an adequate number $(7-12)$ of leaf buds on bearing shoots of intermediate length.

The ratio of flower buds/all buds indicates well the "tendency of whip formation" of the respective variety. In "whip forming" varieties the ratio is high: 0.62 (Pandy meggy) and 0.67 (Újfehértói fürtös), whereas it is lower in less inclined varieties: 0.46 (Körösi korai) and 0.57 (Érdi jubileum). Bud numbers and ratios of Érdi bốtermó are between the two former categories.

A regular yield of the varieties is secured by a high number bearing shoots formed inevery subsequent year. Varieties of a high tendency to forming "whips" (and high flower densities) develop but a few leaf buds on short (below $10 \mathrm{~cm})$ and medium long (10-40 cm) shoots. All shoots may continue growing by their apical buds, only, thus develop no branches. For the purpose to secure the yield of the next year, a more vigorous growth should be stimulated. In "whip forming" varieties, shoots of more than $40 \mathrm{~cm}$ length should be raised, where in less inclined ones, this limit could be taken at $30 \mathrm{~cm}$ in order to restitute the balance between flower and leaf buds. On the long shoots (above $60 \mathrm{~cm}$ ) all varieties develop a low ratio of flower buds (17-35\%).

Summing up the results, it is stated that among the sour cherry varieties studied Pándy meggy, Keceli l, Újfehértói fürtös and Érdi bôtermố should be influenced to produce $40-50 \mathrm{~cm}$-long shoots in order to balance out their actual and future capacity of yielding. Whereas Körösi korai and Érdi jubileum will develop an adequate ratio (1) of flower/leaf buds on shorter $30-40 \mathrm{~cm}$-long shoots. More vigorous (above $50 \mathrm{~cm}$ long) shoots develop a low ratio of flower buds $(13-36 \%)$. That policy may lower the yield of the respective year, but the enhanced flower bud formation promises a higher yield of the next year. An excessive vigour may lower, drastically, the fruit set and yields according to Rasmussen et al. (1983). The sour cherry Stevnsboer set half as many fruits on 40-50 cm long shoots and one eight as many on 50-60 cm long shoots than on the shoots shorter than $40 \mathrm{~cm}$.

Sour cherry varieties inclined to develop "whips" should be pruned more severely in order to induce longer (40-50 $\mathrm{cm}$ ) shoots on the tree. That way, the branches do not get barren, and develop branches from the side buds, where new bearing shoots may appear. If "whip formation" is not expected on the varieties, $30-40 \mathrm{~cm}$ shoot growth per year should be maintained. A balance of yielding and flower bud formation is secured in sour cherry production by the described policies.

\section{Plum}

Hassib (1966) explored the effect of several factors on the development of buds on plum shoots. He stated that less flower buds are formed on the lower part of the tree than on the upper region. Flower density is higher on horizontal shoots than on the vertical ones. Among the long shoots, the medium thick ( $6 \mathrm{~mm}$ diametre) ones bore the most flower buds. On the same shoot, the shorter internodia are armed, preferably, with flower buds. Some varieties (e.g. Althann ringló) are inclined to develop "whips" like some sour cherry varieties (Wustenberghs et al., 1994). This type of varieties are not suitable for intense cultivation, high yields are possible on large crowns, only. The tendency to form short spurs, which may continue growing by the apical leaf bud, only, the rest being flower buds, thus no branching is possible.

Data related to flower bud and flower densities of many years are available in European and Japanese plums and are summarised in Table 4. The data presented are means derived from shoots of different varieties and lengths. Earlier (Szabó, 1989) the densities are referred to $1 \mathrm{~m}$ length of the shoot, however, actually $1 \mathrm{~cm}$ means are calculated. According to the observations flower bud and flower

Table 4 Density of flower buds and flowers in plum varieties (Siófok, 1982-1985)

\begin{tabular}{|c|c|c|c|}
\hline \multirow[t]{2}{*}{ Variety } & \multirow{2}{*}{$\begin{array}{c}\text { Density } \\
\text { of flower buds } \\
\text { (bud } / \mathrm{cm} \text { ) }\end{array}$} & \multicolumn{2}{|c|}{ Number of flowers } \\
\hline & & (flower $/ \mathrm{cm})$ & (flower/fl.bud) \\
\hline \multicolumn{4}{|l|}{ European plums } \\
\hline Ageni & 0.95 & 1.10 & 1.2 \\
\hline Besztercei Bt. 2 & 0.60 & 0.72 & 1.2 \\
\hline Bluefre & 0.85 & 1.61 & 1.9 \\
\hline Cacanska najbolja & 1.27 & 1.63 & 1.3 \\
\hline Cambridge Gage & 0.52 & 0.77 & 1.5 \\
\hline Czar & 0.53 & 1.18 & 2.2 \\
\hline Debreceni muskotály & 0.42 & 0.74 & 1.8 \\
\hline Early Italian & 0.50 & 0.73 & 1.5 \\
\hline Early Laxton & 1.37 & 2.08 & 1.5 \\
\hline Growers Late Victoria & 0.65 & 1.10 & 1.7 \\
\hline Krikon & 0.46 & 0.68 & 1.5 \\
\hline Olasz kék & 0.57 & 0.81 & 1.4 \\
\hline Ontario & 0.59 & 0.80 & 1.4 \\
\hline Pozegaca & 0.38 & 0.45 & 1.2 \\
\hline President & 1.04 & 1.94 & 1.9 \\
\hline Reine-Claude de Bavay & 0.65 & 1.13 & 1.7 \\
\hline Richards Early Italian & 0.47 & 0.85 & 1.8 \\
\hline Ruth Gerstetter & 0.77 & 1.30 & 1.7 \\
\hline Stanley & 0.65 & 1.08 & 1.7 \\
\hline Tuleu timpuriu & 1.31 & 2.12 & 1.6 \\
\hline Victoria & 0.78 & 1.37 & 1.8 \\
\hline Zöld ringló & 0.65 & 0.93 & 1.4 \\
\hline \multicolumn{4}{|l|}{ Japanese plums } \\
\hline Burbank & 1.63 & 2.56 & 1.6 \\
\hline Duarte & 1.43 & 2.25 & 1.6 \\
\hline Elephant Heart & 1.91 & 2.63 & 1.4 \\
\hline Methley & 1.26 & 1.94 & 1.5 \\
\hline Santa Rosa & 1.03 & 1.73 & 1.7 \\
\hline Shiro & 2.69 & 3.59 & 1.3 \\
\hline
\end{tabular}

(Source: Szabó, 1989 calculated according to his data) 
densities are much higher in Japanese plums than in European plums. The densities varied between 0.42 and 1.37 flower buds/cm in European plums, whereas between 1.03 and 2.69 in Japanese plums. Flower densities were even higher because plums develop often more than one flower per bud: $1-2$ in European and 2-3 in Japanese plums. In Japanese plums, the number of flowers primordia may be even higher, but the winter frosts often kill some of them and diminish the possible number of flowers. Thus flower density in Japanese plums may surpass the flower bud densities by $50-100 \%$ if all primordia were developed.

Copious yields are conditioned by a high density of flower buds and, subsequently, a profuse load of flowers. The higher flower density the better yield is proved in Table 5. At the same time, however, ecessive flower densities may diminish ultimate fruit set by depriving food reserves (Stover, 2000). This relation has proved by our own calculations because plum and peach varieties with high flower densities are by no means more profusely yielders than those with a low flower density. The correlation is unequivocal though its tightness is yearly variable.

Studies performed at Siófok (Szabó, 1989) contributed to the proofs of the correlation between flower density and the subsequent rate of fruit set (Table 5). Both in European and Japanese plum varieties, the correlation has been negative, i.e. higher flower densities were followed by lower rates of fruit set. The same invers relation also has been valid in open pollinated self-fertile European plums. The results are proofs of Stover's (2000) statements that growing flower density lowers the rate of fruit set. According to Pozvai et al. (1982) the same negative correlation is experienced in sour cherry in relation to open pollinated flowers too. At the same time, flower density and yield are, unequivocally correlated, positively. It is proved by our assessments at Kecsemét.

\section{Peach}

Among stone fruits, peach is the most exposed to "oversetting" that means, excessive fruit set, which lowers prices by the smaller diameter of fruits. Peaches are, on the contrary, most liable to be regulated by phytotechnical means (e.g. pruning, thinning of buds). That is, most likely, the reason why fruiting conditions of the peach are explored, most thoroughly. The quantity of flower buds visible on the shoots give a clear (optimistic) idea on the yield expected. That is proved by biometrical arguments revealed in Table 5 . Flower density and fruit load are tightly correlated.

The number of buds per length of the shoot is considered to be a relatively stable parameter (Werner et al., 1988). Thus, flower bud density is a charcteristic varietal trait, which predicts the yielding ability of the particular varietiy. (Brózik, 1962; Bellini és Scaramuzzi, 1976).

Mohácsy et al. (1959) analysed the relation between shoot charcters and flower bud density. The data of the latter served to set the principles of pruning techniques.

In 1986, at Siófok 42 peach varieties (17 for, fresh consumption, 10 processing clingstones and 15 nectarines) have been screened for shoot length and quality as well as

Table 5 Correlation between flower density, fruit set and fruit load

\begin{tabular}{|c|c|c|c|c|c|c|}
\hline Species & Growing site & Year & Components of the correlation & $\begin{array}{c}\text { Number of } \\
\text { varieties } \\
\text { studied }\end{array}$ & $\begin{array}{c}\text { Coefficient of } \\
\text { correlation } \\
r\end{array}$ & $\begin{array}{c}\text { Significance of } \\
\text { the correlation } \\
\mathrm{P} \%\end{array}$ \\
\hline \multirow[t]{6}{*}{ European plums } & \multirow[t]{5}{*}{ Siófok } & 1982 & $\begin{array}{l}\text { Flower density / Self compatibility } \\
\text { Flower density / Fruit set in open pollination }\end{array}$ & $\begin{array}{l}6 \\
7\end{array}$ & $\begin{array}{l}-0.763 \\
-0.916\end{array}$ & $\begin{array}{l}5 \\
0.1\end{array}$ \\
\hline & & 1983 & $\begin{array}{l}\text { Flower density / Self compatibility } \\
\text { Flower density / Fruit set in open pollination }\end{array}$ & $\begin{array}{l}8 \\
9 \\
\end{array}$ & $\begin{array}{r}-0.410 \\
-0.510 \\
\end{array}$ & $\begin{array}{l}\text { n. s. } \\
\text { n. s. }\end{array}$ \\
\hline & & 1984 & $\begin{array}{l}\text { Flower density / Self compatibility } \\
\text { Flower density / Fruit set in open pollination }\end{array}$ & $\begin{array}{l}13 \\
19 \\
\end{array}$ & $\begin{array}{r}-0.292 \\
-0.567 \\
\end{array}$ & $\begin{array}{l}\text { n. s. } \\
0.1\end{array}$ \\
\hline & & 1985 & $\begin{array}{l}\text { Flower density / Self compatibility } \\
\text { Flower density / Fruit set in open pollination }\end{array}$ & $\begin{array}{l}16 \\
24 \\
\end{array}$ & $\begin{array}{l}-0.646 \\
-0.438 \\
\end{array}$ & $\begin{array}{l}1 \\
5 \\
\end{array}$ \\
\hline & & $1982-1985$ & $\begin{array}{l}\text { Flower density / Self compatibility } \\
\text { Flower density / Fruit set in open pollination }\end{array}$ & $\begin{array}{l}16 \\
24 \\
\end{array}$ & $\begin{array}{l}-0.759 \\
-0.629 \\
\end{array}$ & $\begin{array}{l}0.1 \\
0.1\end{array}$ \\
\hline & Kecskemét & 1988 & $\begin{array}{l}\text { Flower load / Fruit set in open pollination } \\
\text { Flower load / Fruit load }\end{array}$ & $\begin{array}{l}43 \\
43\end{array}$ & $\begin{array}{r}-0.1046 \\
0.6268 \\
\end{array}$ & $\begin{array}{l}\text { n. s. } \\
0.1\end{array}$ \\
\hline \multirow[t]{3}{*}{ Japanese plums } & Siófok & $1982-1985$ & Flower density / Fruit set in open pollination & 6 & -0.471 & n. s. \\
\hline & Kecskemét & 1988 & Flower load / Fruit set in open pollination & 43 & -0.1046 & n. $s$. \\
\hline & & & Flower load / Fruit load & 43 & 0.6268 & 0.1 \\
\hline \multirow[t]{3}{*}{ Peaches } & Siófok & 1986 & Flower load / Fruit load & 72 & 0.3127 & 0.1 \\
\hline & Szigetcsép & 1993 & Flower load / Fruit load & 93 & 0.8704 & 0.1 \\
\hline & Szatymaz & 1998 & $\begin{array}{l}\text { Flower load / Fruit set in open pollination } \\
\text { Flower load / Fruit load }\end{array}$ & $\begin{array}{l}48 \\
60\end{array}$ & $\begin{array}{r}-0.1160 \\
0.5343\end{array}$ & $\begin{array}{l}\text { n. s. } \\
0.1\end{array}$ \\
\hline
\end{tabular}

(Source: Szabó, Z. non published)

Explanation: - the unit of flower density is flower/cm.

- flower and fruit load is expressed on a scale of $0-10=$ no flower or no fruit, $10=$ maximal load assessed by estimation,

- self fertility and fruit set by open pollination is characterised by the rates of fruit set or fruits developed per flowers $(\%)$,

- n. s. = not significant. 
location of buds. Shoots got into 4 categories (more than 60 $\mathrm{cm}, 40-60 \mathrm{~cm}, 10-40 \mathrm{~cm}$, less than $10 \mathrm{~cm})$. Varieties, variety-groups as well as shoot categories displayed substancial differences. Results obtained by study of shoots are presented in Table 6 . The longer, the more are buds on the shoots. The ratio of flower buds per leaf buds was almost in all varieties and shoot categories more than 1. Most diffenece has been found in the short spurs. There the ratio respective variety, but health of the tree and the particular season may modify its value (Werner et al., 1988). Similar rules proved to exist in apple, where an early loss of foliage and heavy infection of e.g. Venturia used to decrease the number of flower buds and fruits developed during the next year in susceptible varieties (Holb, 2001 and 2002). Analogous patterns arte expected in peaches after leaf loss caused by the fungus Taphrina deformans.

Table 6 Distribution and location of buds on different types of shoots in variety types of peach (Siófok 1986)

\begin{tabular}{|c|c|c|c|c|c|c|c|c|c|c|c|c|c|c|c|c|}
\hline \multirow[t]{2}{*}{ Variety type } & \multirow[t]{2}{*}{$\begin{array}{l}\text { Number of } \\
\text { varieties }\end{array}$} & \multirow[t]{2}{*}{$\begin{array}{c}\text { Type of } \\
\text { shoot }\end{array}$} & \multicolumn{2}{|c|}{ Shoot } & \multirow{2}{*}{$\begin{array}{c}\text { Number } \\
\text { of nodes } \\
\text { (nodes } \\
\text { per } \\
\text { shoot) }\end{array}$} & \multirow{2}{*}{$\begin{array}{l}\text { Mean } \\
\text { length } \\
\text { of } \\
\text { inter- } \\
\text { nodes } \\
(\mathrm{mm})\end{array}$} & \multirow{2}{*}{$\begin{array}{c}\text { Total } \\
\text { number } \\
\text { of } \\
\text { buds }\end{array}$} & \multicolumn{2}{|c|}{$\begin{array}{l}\text { Distribution } \\
\text { of buds }(\%)\end{array}$} & \multirow{2}{*}{\begin{tabular}{|c|}
$\begin{array}{c}\text { Flower } \\
\text { bud }\end{array}$ \\
per \\
shoot \\
length \\
$(\mathrm{cm})$
\end{tabular}} & \multicolumn{6}{|c|}{$\begin{array}{l}\text { Distribution of nodes according to the buds born } \\
\text { on them (\%) }\end{array}$} \\
\hline & & & $\begin{array}{c}\text { length } \\
(\mathrm{cm})\end{array}$ & $\begin{array}{c}\text { dia- } \\
\text { meter } \\
(\mathrm{mm})\end{array}$ & & & & leaf & flower & & $\begin{array}{l}\text { no } \\
\text { bud }\end{array}$ & $\begin{array}{l}\text { leaf } \\
\text { bud }\end{array}$ & $\begin{array}{c}\text { flower } \\
\text { bud }\end{array}$ & $\begin{array}{c}\text { leaf \& } \\
\text { flower } \\
1+1\end{array}$ & $\begin{array}{c}\text { leaf \& } \\
\text { flower } \\
1+2\end{array}$ & other \\
\hline \multirow{4}{*}{$\begin{array}{l}\text { Fresh market } \\
\text { types }\end{array}$} & \multirow[t]{4}{*}{17} & 1 & 73.7 & 7.1 & 33.5 & 21.3 & 61.6 & 43.4 & 56.6 & 0.47 & 10.7 & 25.0 & 11.7 & 16.3 & 34.5 & 4.0 \\
\hline & & $\mathrm{im}$ & 49.6 & 5.4 & 28.2 & 17.9 & 43.7 & 41.7 & 58.3 & 0.51 & 15.0 & 21.8 & 17.9 & 12.2 & 29.3 & 4.6 \\
\hline & & s & 32.8 & 3.6 & 19.7 & 16.7 & 26.8 & 35.6 & 64.4 & 0.53 & 11.9 & 19.1 & 36.4 & 12.1 & 18.3 & 3.6 \\
\hline & & sp & 7.8 & 2.8 & 7.4 & 10.5 & 9.1 & 20.8 & 79.2 & 0.92 & 20.8 & 9.4 & 58.7 & 7.6 & 7.7 & 5.0 \\
\hline \multirow{4}{*}{$\begin{array}{l}\text { Processing } \\
\text { clingstones }\end{array}$} & \multirow[t]{4}{*}{10} & 1 & 77.3 & 7.0 & 32.9 & 23.5 & 69.1 & 36.4 & 63.6 & 0.57 & 7.9 & 13.4 & 12.6 & 12.2 & 50.3 & 4.0 \\
\hline & & $\mathrm{im}$ & 52.0 & 5.2 & 25.8 & 20.1 & 45.4 & 33.1 & 66.9 & 0.58 & 11.8 & 13.4 & 22.1 & 12.9 & 31.5 & 8.3 \\
\hline & & s & 31.6 & 3.9 & 18.3 & 17.4 & 26.5 & 26.8 & 73.2 & 0.61 & 19.6 & 8.0 & 37.4 & 12.2 & 18.1 & 10.5 \\
\hline & & $\mathrm{sp}$ & 8.0 & 3.1 & 8.1 & 9.9 & 8.8 & 14.1 & 85.9 & 0.94 & 14.7 & 4.1 & 58.7 & 6.1 & 6.4 & 7.2 \\
\hline \multirow[t]{3}{*}{ Nectarines } & \multirow[t]{3}{*}{15} & 1 & 74.2 & 6.4 & 30.1 & 24.6 & 66.6 & 37.9 & 62.1 & 0.56 & 6.9 & 17.0 & 8.8 & 11.3 & 48.6 & 10.5 \\
\hline & & $\mathrm{s}$ & 32.5 & 3.9 & 18.0 & 17.9 & 30.5 & 30.1 & 69.9 & 0.66 & 7.8 & 7.8 & 33.8 & 11.3 & 25.7 & 11.4 \\
\hline & & $\mathrm{sp}$ & 7.1 & 2.5 & 7.8 & 9.1 & 7.7 & 23.9 & 76.1 & 0.83 & 22.3 & 8.3 & 52.6 & 9.9 & 5.8 & 10.2 \\
\hline
\end{tabular}

(Source: Kapás, Zs. - Szabó, Z. \& Nyéki, J.: non published)

Explanation: $1=$ long shoot above $60 \mathrm{~cm}$.

$\mathrm{im}=$ intermediate shoot length between $40-60 \mathrm{~cm}$.

of flower buds attained or surpassed $80 \%$, and they were mainly single buds. The bud triplets (one leaf bud between two flower buds), which are maintained to be the most desirable, appeared most abundantly (on $40-50 \%$ of nodes) in the category of long shoots. Observations corroborate the statements of Mohácsy et al. (1959) derived from the study of four varieties. The 3 groups of varieties are compared, therefore, on the base of data of the most valuable long shoots. The longest internods $(24.6 \mathrm{~mm})$ are found in nectarines, the shortest ones $(21.3 \mathrm{~mm})$ in, fresh consumption types. Density of flower buds is similar in nectarines $(0.56 \mathrm{bud} / \mathrm{cm})$ and processing clingstones $(0.57)$, and substantially lower in fresh consumption types (0.47). Lowest values of flower bud ratio are found in fresh consumption types (56.6\%). Distribution of buds on nods is similar in processing varieties and nectarines. The frequency of single leaf buds are highest in fresh consumption types and triple buds are less frequent in relation to the other two groups of varieties.

Results obtained at three growing sites are summarised in the Tables 7-10. It turned out that in data of flower bud density there are significant differences among varieties. Flower bud density is a rather stable character of the $\mathrm{s}=$ short shoot between $10-40 \mathrm{~cm}$.

$\mathrm{sp}=$ spur less than $10 \mathrm{~cm}$.
Our data facilitate also the analysis of effects of growing sites on the flower density of the same varieties. In spite of considerably variable conditions differences proved to be relatively small. In Tables $7-10$, the site of origin of each variety has been indicated. It could be stated as Werner et al. (1988) claimed that flower bud density is related to the region, where the variety has been found and registrated (Table 11). Where the security of yield is a critical condition of success (states of Georgia and New Jersey in the USA), frost resistance and high flower bud density was important. High flower bud density of the variety may be a nuisance where fruit set has high probability because the necessary fruit thinning operations are costly. Varieties arisen in those regions (California in USA and the region of Rome in Italy) develop less flower buds. Among the Californian and New Jersey varieties are some, which are different in fruit bud density, but the majority is typical to the respective region. There are, however, varieties derived from Michigan of USA and Ontario of Canada, as well as from Hungary. Yield security is though important in those regions, but their intermediate flower bud density $(0.41-0.60 \mathrm{bud} / \mathrm{cm})$ is associated with frost resistance, which will be a pawn of regular yields 
Table 7 Flower bud densities of fresh market type, yellow fleshed peach varieties

(Locations and dates: Siófok 1986; Szigetcsép 1993-1994; Szatymaz 1997)

\begin{tabular}{|c|c|c|}
\hline Variety & $\begin{array}{c}\text { Country and native town } \\
\text { of the variety }\end{array}$ & $\begin{array}{c}\text { Flower bud } \\
\text { density } \\
\text { (bud/cm) }\end{array}$ \\
\hline Aranycsillag & Hungary, Szeged & 0.51 \\
\hline Aurelia & Italy, Rome & 0.29 \\
\hline Biscoe & USA, North Carolina, Raleigh & 0.65 \\
\hline Blazing Gold & USA, California, Merced & 0.57 \\
\hline Collins & USA, New Jersey, New Brunswick & 0.73 \\
\hline Cresthaven & USA, Michigen, East Lansing & 0.50 \\
\hline Dixired & USA, Georgia, Byron & 0.45 \\
\hline EarliGlo & Canada, Ontario State & 0.45 \\
\hline Early Redhaven & USA, Washington State & 0.49 \\
\hline Elberta & USA, Georgia, Marshallville & 0.48 \\
\hline Elagant Lady & USA, California, Red Bluff & 0.40 \\
\hline Fayette & USA, California, Fresno & 0.44 \\
\hline Flaminia & Italy, Rome & 0.57 \\
\hline Flavorcrest & USA, California, Fresno & 0.42 \\
\hline Gloria Red & Hungary, Szeged & 0.34 \\
\hline Halehaven & USA, Michigan, East Lansing & 0.53 \\
\hline Harbinger & Canada, Ontario, Harrow & 0.30 \\
\hline Harbrite & Canada, Ontario, Harrow & 0.42 \\
\hline Jerseyland & USA, New Jersey, New Brunswick & 0.42 \\
\hline July Elberta & USA, California, Santa Rosa & 0.43 \\
\hline July Lady & USA, California, Red Bluff & 0.47 \\
\hline Lacika-féle & Hungary, Szeged & 0.59 \\
\hline Laure & France & 0.51 \\
\hline Laurence & France & 0.50 \\
\hline Lisbeth & USA, California, Red Bluff & 0.31 \\
\hline Loring & USA, Missouri, Mountain Grove & 0.54 \\
\hline Maria Luisa & Italy, Florence & 0.22 \\
\hline Maycrest & USA, California, Reedley & 0.40 \\
\hline Merrill Sundance & USA, California, Red Bluff & 0.45 \\
\hline Óvári-féle & Hungary, Szeged & 0.55 \\
\hline Ranger & USA, Maryland, Kearnaysville & 0.50 \\
\hline Redcap & USA, Georgia, Byron & 0.59 \\
\hline Redgold & USA, Alabama, Bangor & 0.49 \\
\hline Redhaven & USA, Michigan, East Lansing & 0.55 \\
\hline Redkist & USA, Michigan, Watervliet & 0.34 \\
\hline Redskin & USA, Maryland, College Park & 0.41 \\
\hline Redtop & USA, California, Fresno & 0.44 \\
\hline Regina & USA, Maryland, Kearnaysville & 0.38 \\
\hline Rosired 1 & Italy, Bologna & 0.45 \\
\hline Rosired 3 & Italy, Bologna & 0.47 \\
\hline Royal April & USA, California, Modesto & 0.13 \\
\hline Royal Gold & USA, California, Modesto & 0.50 \\
\hline Sentry & USA, Maryland, Kearneysville & 0.26 \\
\hline Springcrest & USA, Georgia, Byron & 0.36 \\
\hline Springold & USA, Georgia, Byron & 0.80 \\
\hline Starcrest & France & 0.43 \\
\hline Starking Delicious & USA, Arkansas, Dover & 0.54 \\
\hline Suncrest & USA, California, Fresno & 0.45 \\
\hline Sunhaven & USA, Michigan, East Lansing & 0.42 \\
\hline Szegedi Arany & Hungary, Szeged & 0.43 \\
\hline
\end{tabular}

(Source: Kapás, Zs. - Szabó, Z. - Nyéki, J. non published; Gábris, A. Szabó, Z. - Dávid, M. non published; Szabó et al. 1998)
Table 8 Flower bud densities of fresh consumption, white fleshed peach varieties

(Siófok 1986; Szigetcsép 1993-1994; Szatymaz 1997)

\begin{tabular}{|l|l|c|}
\hline \multicolumn{1}{|c|}{ Variety } & Country and native town of the variety & $\begin{array}{c}\text { Flower bud } \\
\text { density } \\
\text { (bud/cm) }\end{array}$ \\
\hline Champion & USA, Ilionis, Nolomis & 0.41 \\
Ford & USA, West Virginia & 0.49 \\
Genadix 4 & France, Bordeaux & 0.58 \\
Impero & Italy & 0.49 \\
Incrocio Pieri & Italy, Pistoia & 0.43 \\
Manon & France, Bouches du Rhone & 0.38 \\
Maria Bianca & Italy, Firenze & 0.47 \\
Meystar & France & 0.50 \\
Michelini & Italy & 0.41 \\
Piroska & Hungary & 0.75 \\
Piros Mariska & Hungary & 0.50 \\
Primerose & USA, California & 0.52 \\
Raritan Rose & USA, New Jersey, New Brunswick & 0.97 \\
Redhaven Bianca & Italy & 0.54 \\
Redwing & USA, California, Ontario & 0.50 \\
Robin & USA, California, Ontario & 0.49 \\
Springtime & USA, California, Ontario & 0.52 \\
Starlite & USA, Georgia, Byron & 0.59 \\
\hline
\end{tabular}

(Source: Kapás, Zs. - Szabó, Z. - Nyéki, J. non published; Gábris, A. Szabó, Z. - Dávid, M. non published; Szabó et al., 1998)

Table 9 Flower bud densities of processing clingstone, peach varieties

(Siófok 1986; Szigetcsép 1993-1994; Szatymaz 1997)

\begin{tabular}{|l|l|c|}
\hline Variety & Country and native town of the variety & $\begin{array}{c}\text { Flower bud } \\
\text { density } \\
\text { (bud/cm) }\end{array}$ \\
\hline Adriatica & Italy, Bologna & 0.54 \\
Babygold 5 & USA, New Jersey, New Brunswick & 0.47 \\
Babygold 6 & USA, New Jersey, New Brunswick & 0.50 \\
Babygold 7 & USA, New Jersey, New Brunswick & 0.50 \\
Babygold 9 & USA, New Jersey, New Brunswick & 0.60 \\
Frederica & USA, Maryland & 0.66 \\
Loadel & USA, California, Yuba City & 0.62 \\
Shasta & USA, California, Polo Alto & 0.47 \\
Sudanell & Spain & 0.47 \\
Tebana & Italy, Bologna & 0.51 \\
Troubador & France & 0.65 \\
Vesuvio & Italy & 0.59 \\
\hline
\end{tabular}

(Source: Kapás, Zs. - Szabó, Z. - Nyéki, J. non published; Gábris, A. Szabó, Z. - Dávid, M. non published; Szabó et al., 1998) 
Table 10 Flower bud densities of nectarine varieties (Siófok 1986; Szigetcsép 1993-1994; Szatymaz 1997)

\begin{tabular}{|c|c|c|}
\hline Variety & Country and native town of the variety & $\begin{array}{l}\text { Flower bud } \\
\text { density } \\
\text { (bud/cm) }\end{array}$ \\
\hline Armking & USA, California, Ontario & 1.10 \\
\hline Bóka-féle & Hungary & 0.46 \\
\hline Cherokee & USA, Virginia, Blacksburg & 0.50 \\
\hline Domiziana & Italy, Rome & 0.44 \\
\hline Fairlane & USA, California, Fresno & 0.43 \\
\hline Fantasia & USA, California, Fresno & 0.47 \\
\hline Flamekist & USA, California, Fresno & 0.48 \\
\hline Flavortop & USA, California, Fresno & 0.40 \\
\hline Fuzador & France, Bordeaux & 0.59 \\
\hline Fuzalode & France, Bordeaux & 0.56 \\
\hline Croce del Sud & Italy, Rome & 0.25 \\
\hline Harblaze & Canada, Ontario, Harrow & 0.30 \\
\hline Harko & Canada, Ontario, Harrow & 0.60 \\
\hline Independence & USA, California, Fresno & 0.39 \\
\hline July Red & USA, California,'Le Grand & 0.35 \\
\hline June Star & USA, California, Le Grand & 0.52 \\
\hline Lafayette & USA, Virginia, Blacksburg & 0.64 \\
\hline Le Grand & USA, California, Le Grand & 0.45 \\
\hline Maria Aurelia & Italy, Florence & 0.38 \\
\hline Maria Carla & Italy, Florence & 0.38 \\
\hline Maria Laura & Italy, Florence & 0.36 \\
\hline Maybelle & USA, California & 0.68 \\
\hline Mayfire & USA, California, Fresno & 0.68 \\
\hline Morton & USA, New York, Geneva & 0.62 \\
\hline Nataly & USA, New Jersey, New Brunswick & 0.44 \\
\hline Nectagrand 1 & Italy, Bologna & 0.78 \\
\hline Nectagrand 4 & Italy, Bologna & 0.28 \\
\hline Nectaheart & USA, New Jersey, New Brunswick & 0.68 \\
\hline Nectared 5 & USA, New Jersey, New Brunswick & 0.57 \\
\hline Nectared 6 & USA, New Jersey, New Brunswick & 0.83 \\
\hline Nectarose & USA, New Jersey, New Brunswick & 0.63 \\
\hline Nectaross & Italy, Rome & 0.46 \\
\hline Olympio & France, Bordeaux & 0.37 \\
\hline Orion & Italy, Rome & 0.34 \\
\hline Pegaso & Italy, Rome & 0.60 \\
\hline Pocahontas & USA. Virginia, Blacksburg & 0.38 \\
\hline Redchief & USA, Virginia, Blacksburg & 0.64 \\
\hline Red June & USA, California, Le Grand & 0.55 \\
\hline Scarlet Red & USA, California, Le Grand & 0.30 \\
\hline September Red & USA, California, Le Grand & 0.26 \\
\hline Silver Lode & USA, California, Ontario & 0.74 \\
\hline Snow Queen & USA, California, Ontario & 0.43 \\
\hline Stark Delicious & USA, California, Le Grand & 0.36 \\
\hline Stark Redgold & USA, California, Le Grand & 0.41 \\
\hline Stark Sunglo & USA, Kalifornia, Le Grand & 0.56 \\
\hline Venus & Italy. Rome & 0.41 \\
\hline Weinberger & Italy, Rome & 0.33 \\
\hline $11 / 6$ & France & 0.41 \\
\hline
\end{tabular}

(Source: Kapás, Zs. - Szabó, Z. - Nyéki, J. non published; Gábris, A. Szabó, Z. - Dávid, M. non published; Szabó et al., 1998)

\section{The probability of flower buds on different parts of the shoots}

Figure 2 shows the fruit bud densities of the varieties Fuzador (0.72 flower bud/cm), Redhaven (0.52) and
Table 11 Flower bud density of peach varieties according to their origin (Siófok 1986: Szigetcsép 1993-1994: Szatymaz 1997)

\begin{tabular}{|l|c|c|c|c|}
\hline \multicolumn{1}{|c|}{$\begin{array}{c}\text { Locality of origin } \\
\text { of varieties }\end{array}$} & Number of & \multicolumn{3}{|c|}{ Flower bud density (bud/cm) } \\
\cline { 3 - 6 } & varieties & Minimum & Maximum & Mean \\
\hline Italy, Rome & 8 & 0.29 & 0.60 & 0.430 \\
USA, Michigan+Canada, Ontario & 10 & 0.30 & 0.60 & 0.441 \\
USA, California & 38 & 0.13 & 1.10 & 0.476 \\
Hungary & 9 & 0.25 & 0.75 & 0.487 \\
USA, Georgia & 6 & 0.45 & 0.80 & 0.545 \\
USA, New Jersey & 13 & 0.42 & 0.97 & 0.614 \\
\hline
\end{tabular}

(Source: calculations are based on: Kapás, Zs. - Szabó, Z. - Nyéki. J. non published; Gábris, A. - Szabó, Z. - Dávid, M. non published; Szabó et al., 1998)

Flavortop (0.44), which represent a high, intermediate and a low density, respectively, observed in an assessment at Siófok. All peach varieties develop less flower buds at the base and at the tip. The middle region of the shoot in Fuzador developed mixed goups of triple buds, whereas the other two varieties displayd a reduced number of buds also at the middle region of the shoot. More flower buds are developed at the parts, where the internods are longer than $20 \mathrm{~mm}$. The longest internods on the middle part of shoots (longer than $30 \mathrm{~mm}$ ) show the lowest fruit bud densities on the shoots of Flavortop. The invers relation (negative correlation) of the two phenomena cannot be proved to be significant with the data obtained at Siófok in a sample of 38 varieties.

\section{Classification of varieties according to flower bud density}

Hugard \& Saunier (cit Ninkovski, 1982) distinguished low $(0.50$ flower bud $/ \mathrm{cm}$ or less), intermediate $(0.50-0.75)$ and high (more then 0.75) categories among varieties. Bellini \& Scaramuzzi (1976) called this parameter index of fertility and drew its boundaries at below $0.30,0.30-0.70$ and above 0.70 flower bud/cm; Timon (1998) in turn below $0.50,0.51-0.65$, above 0.65 .

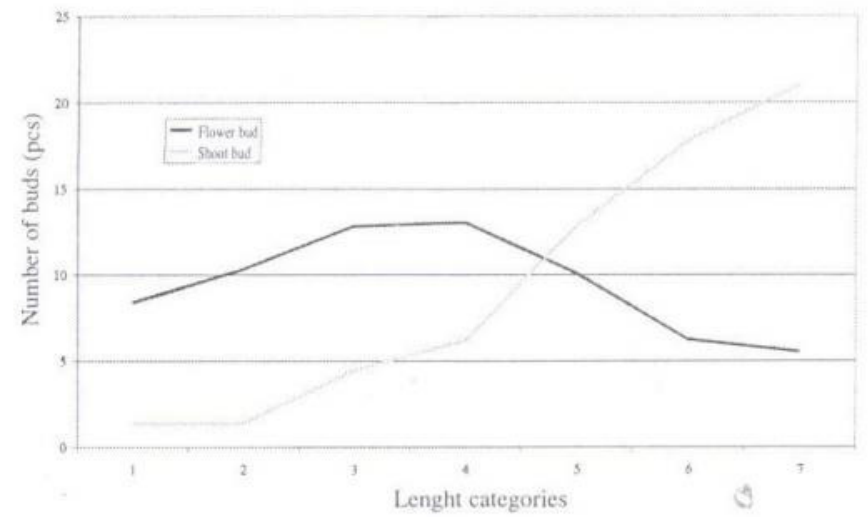

Figure I Number of flower buds according to the lenght of the sour cherry shoot (Source: Kovács, S.-Katona, É.-Szabó, Z. non published) 


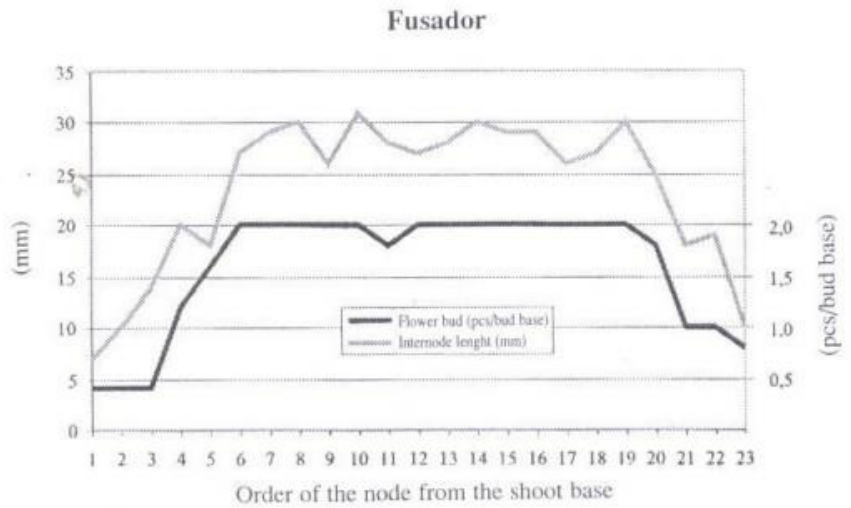

Redhaven

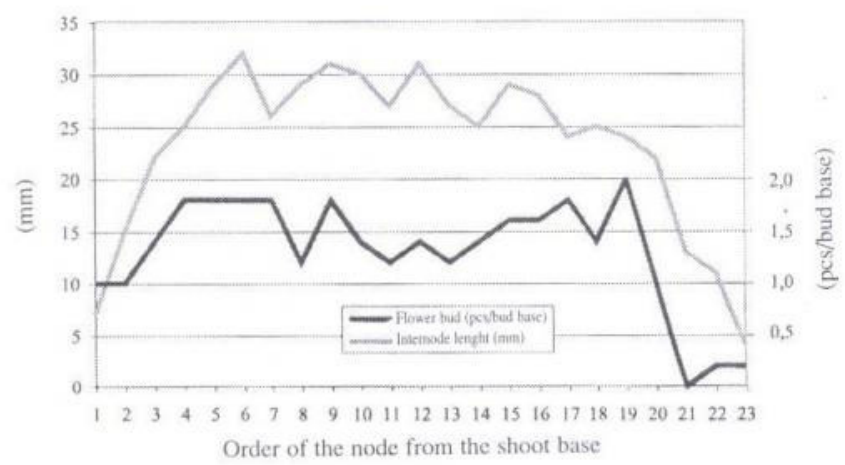

Flavortop

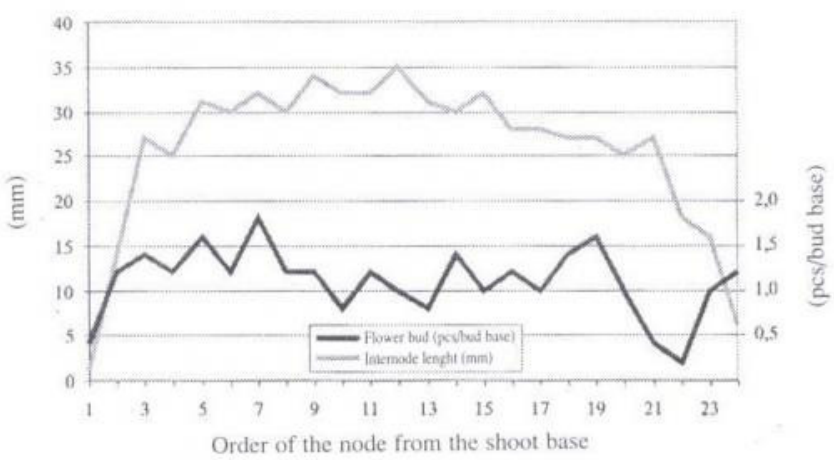

Figure 2 Number of flower buds on the different part of the peach shoot (Source: Kapás, Zs.-Szabó, Z.-Nyéki, J. non published)

According to the present authors set the following categories:

low $=$ below 0.41 flower bud $/ \mathrm{cm}$,

intermediate $=$ between 0.40 and 0.60 flower $\mathrm{bud} / \mathrm{cm}$,

high $=$ above 0.60 flower bud $/ \mathrm{cm}$.

Distribution of the current varieties accordung that scheme is presented in Figure 3. Most typical is the value found between 0.41 and 0.50 flower bud $/ \mathrm{cm}$. The majority of varieties $(62 \%)$ is assigned to the intermediate category. Excessive values have been found too, either small (0.13) or large (1.10). Among 129 varieties 68 were market fresh types, 12 processing clingstones, and 49 nectarines (Table 12). The fresh consumption types and nectarines are

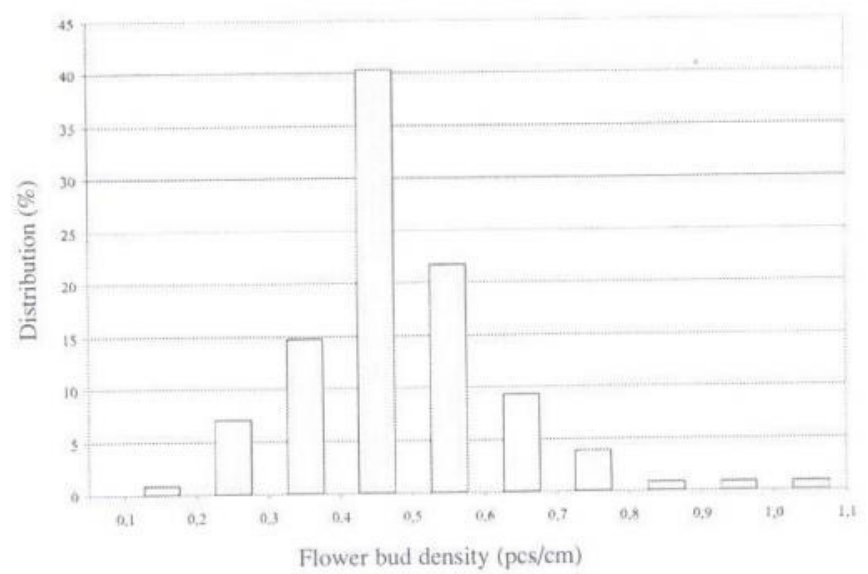

Figure 3 Distribution of peach varieties (129) according the flower bud densities (Source: Szabó, Z. non published)

represented in all the three categories, whereas the values of processing types occupy a relatively narrow interval (0.47-0.66) comprising intermediate and high values of flower bud density. That may be one of the causes of the relatively balanced fruit loads of the processing clingstones in relation to the other two groups of varieties. The mean values of the three types of varieties did not differ significantly.

\section{Conclusion}

Flower bud density and the spatial distribution of buds are varietal constants of pomology. Flower bud is one

Table 12 Flower bud densities of peaches according to the type of varieties

(Siófok 1986; Szigetcsép 1993-1994; Szatymaz 1997)

\begin{tabular}{|l|c|c|c|c|}
\hline \multirow{2}{*}{ Type of variety } & Number & \multicolumn{3}{|c|}{$\begin{array}{c}\text { Flower bud density (bud/cm) } \\
\text { of }\end{array}$} \\
\cline { 3 - 6 } varieties & minimum & maximum & mean \\
\hline Fresh market types & 68 & 0.13 & 0.97 & 0.477 \\
\hline - yellow fleshed & 50 & 0.13 & 0.80 & 0.457 \\
\hline - white fleshed & 18 & 0.38 & 0.97 & 0.530 \\
\hline Processing clingstones & 12 & 0.47 & 0.66 & 0.548 \\
\hline Nectarines & 49 & 0.25 & 1.10 & 0.497 \\
\hline All varieties & 129 & 0.13 & 1.10 & 0.491 \\
\hline
\end{tabular}

(Source: Kapás, Zs. - Szabó, Z. - Nyéki, J. non published; Gábris, A. Szabó, Z. - Dávid, M. non published; Szabó et al., 1998)

The means did not differ significantly on $\mathrm{P}=5 \%$ level (according to the F-test)

component of productivity, consequently, it is considered in choosing of a variety for plantation. Growing sites where the danger of late frosts is frequent, high flower bud densities are more promising, whereas at a more safe site varieties of low and intermediate flower bud densities are preferable.

A comparison of stone fruit species suggests that apricot and peach develop the lowest flower densities, European plums are intermediate, sweet and sour cherry and Japanese plum bear, relatively, the most flowers. 
The quantity of flower buds is an essential condition of the next yield, however, the right ratio of flower buds and leaf buds, in turn, is a pledge of the future yields because the yielding structures of the next years ought to be developed, continuously. The systematic survey of bearing structures and flower bud densities of fruit species and varieties will help fruit growers in planning as well as managing of fruit plantations and in estimating yields by considering the potential of particular varieties. It is also an information for choosing pruning policies.

The cultivation of the plantation has to be adapted to the purpose of securing optimal yields not only for the next but also for the later to come. It is the base of deciding upon pruning, fruit thinning and watering. Shoot growth, optimal for the future yielding potential is subject to variation depending on the species and on the varieties. Generally, the varieties known of high flower bud density should be stimulated to develop leaf buds (vegetative growth), whereas, varieties of low flower bud densities are eligible to moderate their growth.

The quantity and ratio of flower buds are not sufficient to decide upon their yield because other components of environmental risk ought to be taken into consideration as frost resistance and conditions of pollination. All those components have to be evaluated together.

\section{References}

Bellini, E. \& Scaramuzzi, F. (1976): Monografia delle principali cultivar di pesco. Vol. II. Consiglio Nazionale delle Ricerche, Firenze, 562.

Brózik, S. (1960): Csonthéjas termésúek. Szilva - Kajszi. Mezốgazdasági Kiadó, Budapest, 71.

Brózik, S. (1962): Csonthéjas termésủek. Ôszibarack. Mezőgazdasági Kiadó, Budapest, 64.

Druart, P. (1996): The relationship between flowering and fruiting of cherry as a function of training system and rootstock. Acta Horticulturae 410: 489-493.

Hassib, M. (1966): Vergleichende Topographie der Blütenknospen bei der Pflaume. Archiv für Gartenbau 14 (5-6): 277-278.
Holb, I. (2001): Az almafavarasodás epidemiológiája integrált és organikus gazdálkodású almaültetvényben. PhD értekezés. DE ATC Mezőggazdaságtudományi Kar, Debrecen pp. 146.

Holb, I. (2002): A betegség járványtani jellemzổi. In: Holb, I. (ed.): Az alma ventúriás varasodása: biológia, elổrejelzés és védekezés. Szaktudás Kiadó Ház, Budapest. 29-55.

Mohácsy, M., Maliga, P. \& ifj. Mohácsy, M. (1959): Az ôszibarack. Mezốgazdasági Kiadó, Budapest, 397.

Ninkovski, I. (1982): Nektarina. Nolit, Beograd, 131.

Pérez-Gonzalez, S. (1993): Bud distribution and yield potential in Peach. Fruit Varieties Journal 47(1): 18-25.

Pozvai, E., Terpó, A. \& Nyéki, J. (1982): A virágsürüség és a gyümölcskötốdés közötti összefüggés meggynél. Botanikai Közlemények 71 (1-2): 137-143.

Rasmussen, K., Kold, E. \& Christensen, I. V. (1983): Blomster opdannelse og frugtsaetning $\mathrm{i}$ relation til scudslaengde hos sauerkirsebaersorten Stevnsbär. Tidsskrift for Planteavl Kobenhavn. 87: 505-514.

Sváb, J. (1981): Biometriai módszerek a kutatásban. Mezốgazdasági Kiadó, Budapest, 557.

Salgim, S. S. (1990): Cseresznye- és meggyfajták virágzása, termékenyülése. Kandidátusi értekezés. MTA Budapest (Manuscript).

Szabó, Z. (1989): Európai és japán szilvafajták virágzása, termékenyülése, társítása. Kandidátusi értekezés, MTA, Budapest (Manuscript).

Szabó, Z., Nyéki, J. \& Soltész, M. (1997): The components of fruit quality in the integrated production of stone fruits. Horticultural Science 29(3-4): 23-30.

Szabó, Z., Nyéki, J., Szél, I., Pedryc, A. \& Szalay, L. (1998): Low temperature injury in peach and nectarine varieties. Acta Horticulturae 465: 399-404.

Timon, B. (1998): Néhány honosítási vizsgálatba vont ốszibarackfajta téli mélynyugalmának és virágrügy berakódottságának vizsgálata. Új Kertgazdaság 30(2): 1-10.

Werner, D. J., Mowrey, B. D. \& Chaparro, J. X. (1988): Variability in flower bud number among peach cultivars. HortScience 23(3): 578-580.

Wustenberghs, H., Belmans, K. \& Keulemans, J. (1994): Preliminary evaluation of the suitalibity of plum cultivars for intensive culture with special emphasis on bare wood formation. Acta Horticulturae 359: 101-106. 